\title{
Article/Artigo
}

\section{Detection of Dientamoeba fragilis in patients with HIV/AIDS by using a simplified iron hematoxylin technique}

\author{
Detecção de Dientamoeba fragilis em pacientes com HIV/AIDS utilizando a técnica de \\ hematoxilina férrica simplificada
}

Juliana Alves Garcia ${ }^{1}$ and Sergio Cimerman ${ }^{2}$

\begin{abstract}
Introduction: Studies strongly indicate Dientamoeba fragilis as one of the causes of diarrhea in human immunodeficiency virus (HIV) patients. Methods: The objective of the present study was to evaluate the prevalence of $D$. fragilis associated with the causes of diarrhea in $82 \mathrm{HIV} /$ AIDS patients hospitalized at the Instituto de Infectologia Emilio Ribas from September 2006 to November 2008. Results: In total, 105 samples were collected from 82 patients. Unprotected sex was the most frequent cause of HIV infection (46.3\%), followed by the use of injectable or non-injectable drugs (14.6\%). Patients presented with viral loads of 49-750,000 copies/ $\mathrm{mL}$ (average: $73,849 \pm 124,850$ copies $/ \mathrm{mL}$ ) and CD4 counts ranging of $2-1,306$ cells $/ \mathrm{mm}^{3}$ (average: $159 \pm 250$ cells $/ \mathrm{mm}^{3}$ ). On an average, the odds of obtaining a positive result by using the other techniques (Hoffman, Pons and Janer or Lutz; Ritchie) were 2.7 times higher than the chance of obtaining a positive result by using the simplified iron hematoxylin method. Significant differences were found between the methods $(p=0.003)$. Conclusions: The other techniques can detect a significantly greater amount of parasites than the simplified iron hematoxylin method, especially with respect to Isospora belli, Cryptosporidium sp., Schistosoma mansoni, and Strongyloides stercoralis, which were not detected using hematoxylin. Endolimax nan $a$ and $D$. fragilis were detected more frequently on using hematoxylin, and the only parasite not found by the other methods was $D$. fragilis.
\end{abstract}

Keywords: Dientamoeba fragilis. Diarrhea. AIDS. Simplified iron hematoxylin.

\section{RESUMO}

Introdução: Estudos indicam a Dientamoeba fragilis como uma das causas de diarréia em pacientes com HIV/AIDS. Métodos: Os objetivos deste estudo foram avaliar a prevalência de $D$. fragilis associadas com as causas de diarréia em pacientes com HIV/AIDS internados no Instituto de Infectologia Emílio Ribas (IIER). Oitenta e dois pacientes internados no IIER fizeram parte deste estudo de setembro de 2006 a novembro de 2008. Resultados: No total, 105 amostras foram coletadas a partir de 82 pacientes neste estudo. Sexo desprotegido foi à causa mais frequente para a aquisição do HIV $(46,3 \%)$, seguido pelo uso de drogas injetáveis ou não injetáveis (14,6\%). Relações heterossexuais foram os mais citados (19,5\%). Pacientes apresentaram carga viral entre 49 e 750.000 (média de $7.849 \pm 124.850$ ) e CD4 variando de 2 a 1.306 (média de $159 \pm 250$ ). Em média, as chances de um resultado ser positivo com outras técnicas foram 2,7 vezes maiores do que a chance de um resultado positivo com hematoxilina férrica simplificada. Foram encontradas diferenças significativas entre os métodos $(\mathrm{p}=0,003)$. Conclusões: As outras técnicas são capazes de detectar uma quantidade significativa maior de parasitas em comparação com a hematoxilina férrica simplificada, especialmente em relação à Isospora belli, Cryptosporidium sp., Schistossoma mansoni e Strongyloides stercoralis que não foram encontrados utilizando a hematoxilina e a Endolimax nana e D. fragilis foram mais detectados pela hematoxilina férrica simplificada, principalmente a $D$. fragilis que não foi detectada pelos outros métodos.

Palavras-chaves: Dientamoeba fragilis. Diarréia. AIDS. Hematoxilina férrica simplificada.

1. Laboratório de Parasitologia, Instituto de Infectologia Emílio Ribas, São Paulo, SP. 2. Instituto de Infectologia Emílio Ribas, $3^{\circ}$ andar, São Paulo, SP.

Address to: Dra. Juliana Alves Garcia. Alameda Sarutaía 73/65, 01403-010 São Paulo, SP, Brasil.

Phone: $55118287-1272$

e-mail: julianagarcia19@yahoo.com.br

Received in 09/01/2011

Accepted in 18/10/2011

\section{INTRODUCTION}

Diarrhea is a common clinical manifestation in patients infected with the human immunodeficiency virus (HIV). It affects people in many underdeveloped countries, but it is also present in developed countries; therefore, it has an impact on the health sector $^{1,2}$.

Parasitic infections are commonly found in acquired immunodeficiency syndrome (AIDS) patients. From the studies on the etiology of diarrhea in AIDS, the study performed by Cimerman reported that parasites are the cause of diarrhea in up to $40 \%$ of these cases ${ }^{3}$.

The involvement of the gut in the course of AIDS is of huge importance, not only because of its frequency but also primarily because of the associated morbidity ${ }^{4}$.

Little is known about the genus Dientamoeba, which was first described in 1918 by Jepps and Dobell, or even about Dientamoeba fragilis, which has a worldwide distribution, causes irritable bowel syndrome, and is associated with allergic colitis and diarrhea in AIDS patients ${ }^{2,5}$.

Dientamoeb a fragilis is almost never investigated, and because there is no consensus on the characterization of this parasite, it appears only in the trophozoite form, which is easily destroyed by the conservation and flotation methods. Therefore, these techniques are not used for this pathogen ${ }^{6}$.

Verification of the possible presence of $D$. fragilis as one of the pathogens that cause diarrhea in AIDS patients is essential, even with respect to their treatment. A simplified iron hematoxylin ( $\mathrm{SIH}$ ) stain was found to be a rapid and effective technique for the diagnosis of $D$. fragilis, considering its sensitivity to and specificity for the parasite.

This study evaluated the efficacy of the SIH stain to identify $D$. fragilis and assessed the prevalence of this parasite in HIV/AIDS patients with diarrhea. 


\section{METHODS}

This was an observational, prospective, and prevalence study. We collected fecal samples from 82 patients from the Instituto de Infectologia Emílio Ribas (IIER), who had a positive serological diagnosis for HIV infection and clinical suspicion of diarrhea.

All the feces samples were smeared for SIH staining (2 slides) and 1 slide each was prepared for the techniques of sedimentation, centrifugation-sedimentation by the formalin-ether $\operatorname{method}^{8}$, and Kinyoun staining 9 . Among the 82 patients for whom clinical data indicated diarrhea, the results for 1 patient were positive for $D$. fragilis.

The patients were informed that they were participating in a clinical study and provided consent.

The following methods were used to detect generic fecal parasites: spontaneous sedimentation, formalin-ether sedimentation, and the Kinyoun staining. SIH staining was used as a specific test for $D$. fragilis.

For statistical analysis of the descriptive variables, we used the following summary measures. For the continuous variables (i.e., age, viral load, and CD4 count), we calculated the average, standard deviation, median, range (minimum and maximum values), and number of patients. For the qualitative variables, their frequency and percentage occurrence in each case are presented. We calculated the $95 \%$ confidence interval (CI) for the proportion of cases of D. fragilis found by the SIH method. We calculated the sample size in order to obtain a CI for the proportion of $D$. fragilis parasites found.

For descriptive analysis, the Statistical Package for Social Sciences (SPSS) version 15 software for Windows was used, while the Number Cruncher Statistical System (NCSS) 2004 and Power Analysis and Sample Size (PASS) 2000 for Windows were used to calculate sample size.

\section{Ethical considerations}

The study was approved by the Ethics Committee of IIER (CEP-IIER) (Research Protocol No. 58/05; approved on June 22, 2006).

\section{RESULTS}

The average age of the 82 patients with HIV/AIDS who participated in this study was 37 years. Twenty (24.4\%) patients were female and $62(75.6 \%)$ were male. From the total population, $16(19.5 \%)$ patients were heterosexual and 12 (14.6\%) were homosexual.

Forty-one (50\%) patients contracted HIV infection through unprotected sex, 12 (14.6\%) through injected drugs, and 5 (6.1\%) through vertical transmission.

CD4+ T cell lymphocyte counts ranged from 2-1,306 cells/ $\mathrm{mm}^{3}$ (median: 51 cells $/ \mathrm{mm}^{3}$ ), while the viral load had a variation of 49-750,000 copies/mL (median: 26,762 copies/mL).

Twenty different symptoms were reported by the study participants. The most common symptoms were diarrhea (95.1\%), fever $(48.8 \%)$, and vomiting $(47.6 \%)$, followed by cough $(15.9 \%)$, weakness, and weight loss (11\%) (Figure 1 and Table 1).

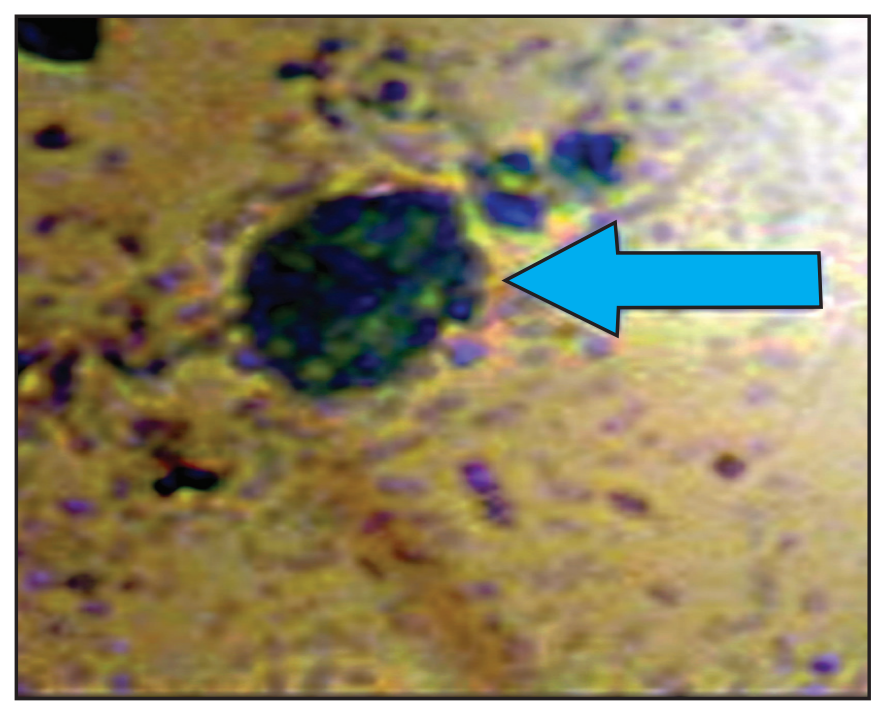

FIGURE 1 - Light microscopy of Dientamoeba fragilis (100× magnification) using the simplified iron hematoxylin stain.

TABLE 1 - Frequency of parasite detection, considering the number of occurrences (total number of patients), for the Hoffman, Ritchie, and Kinyoun methods.

\begin{tabular}{|c|c|c|c|c|c|c|c|c|}
\hline \multirow[b]{2}{*}{ Parasites/techniques } & \multicolumn{2}{|c|}{$\begin{array}{l}\text { Simplified iron } \\
\text { hematoxylin }\end{array}$} & \multicolumn{2}{|c|}{ Hoffman } & \multicolumn{2}{|c|}{ Ritchie } & \multicolumn{2}{|c|}{ Kinyounn* } \\
\hline & $\mathrm{n}^{*}$ & $\%$ & $\mathbf{n}^{*}$ & $\%$ & $\mathbf{n}^{*}$ & $\%$ & $\mathbf{n}^{*}$ & $\%$ \\
\hline Blastocystis hominis & 1 & 1.2 & 1 & 1.2 & 1 & 1.2 & 1 & 1.2 \\
\hline Dientamoeba fragilis** & 1 & 1.2 & 0 & 0.0 & 0 & 0.0 & 0 & 0.0 \\
\hline Endolimax nana & 2 & 2.4 & 3 & 3.7 & 3 & 3.7 & 0 & 0.0 \\
\hline Entamoeba coli & 3 & 3.7 & 3 & 3.7 & 3 & 3.7 & 0 & 0.0 \\
\hline Entamoeba coli/Endolimax nana & 1 & 1.2 & 1 & 1.2 & 1 & 1.2 & 0 & 0.0 \\
\hline Giardia lamblia & 0 & 0.0 & 0 & 0.0 & 3 & 3.7 & 0 & 0.0 \\
\hline Schistosoma mansoni & 0 & 0.0 & 1 & 1.2 & 0 & 0.0 & 0 & 0.0 \\
\hline Strongyloides stercoralis & 0 & 0.0 & 2 & 2.4 & 2 & 2.4 & 0 & 0.0 \\
\hline Strongyloides stercoralis/Schistosoma mansoni & ii 0 & 0.0 & 3 & 3.7 & 3 & 3.7 & 0 & 0.0 \\
\hline Isospora belli & 0 & 0.0 & 0 & 0.0 & 0 & 0.0 & 6 & 7.3 \\
\hline Cryptosporidium sp. & 0 & 0.0 & 0 & 0.0 & 0 & 0.0 & 9 & 11.0 \\
\hline
\end{tabular}

${ }^{*} \mathrm{n}$ : number of patients $=82 ;{ }^{* *} \mathrm{p}<0.001$ (generalization of Fisher's exact test and chi-square test for tables with expected frequencies $<5$ units). 


\section{DISCUSSION}

The population surveyed in this study corresponds to the classic epidemiological pattern of AIDS, as seen in the data reported by the Ministry of Health of Brazil in 2008. Most patients are young adults with an average age of 37 years, and $75.6 \%$ are male and $24.4 \%$ are female. The most common route of HIV infection in this study was from unprotected sex (46.3\%). This study adopted a method involving the use of the Schaudinn fixative with mercuric chloride, which was reported by Horen ${ }^{10}$, in which the core of $D$. fragilis stains better and water is not heated during the preparation of mercuric chloride, as recommended for the traditional SIH technique, because of the toxicity of mercury vapor.

In this study, we found no statistically significant difference between the Hoffman and SIH methods $(\mathrm{p}=0.216)$ or between the SIH and Ritchie methods ( $\mathrm{p}=0.244)$, although some parasites (i.e., Giardia lamblia, Schistosoma mansoni, Strongyloides stercoralis, and Strongyloides stercoralis/Schistosoma mansoni) are most frequently detected with the Hoffman method. D. fragilis was detected in $1.2 \%$ of the 82 patients by using the SIH method and was the only parasite not detected by the Hoffman ${ }^{7}$ and Ritchie ${ }^{8}$ methods, due to the fact that $\mathrm{SIH}$ is a more suitable stain for the detection of trophozoites, as reported by Garcia ${ }^{11}$.

In several studies reporting the detection of this parasite, there was disagreement about the methodology used and divergence among the number of patients studied ${ }^{12-14}$, indicating that in many cases, laboratories are unaware of the staining techniques, leaving the patient without an accurate diagnosis.

Recent molecular studies, such as the one performed by Starcks et al. ${ }^{15}$, have reported a prevalence of $5.2 \%$ for $D$. fragilis, which is higher than that reported in other studies because it used the reverse transcription polymerase chain reaction to detect this parasite. This finding emphasizes the fact that as this test is more sensitive and has less interference than microscopic diagnosis, it could provide a more accurate diagnosis for this parasite.

Lainson and Silva ${ }^{16}$ used the Giemsa technique for 34 HIVpositive patients and detected $D$. fragilis in $3 \%$ of subjects, stating, however, the need for a technique specific for amoebae.

\section{CONFLICT OF INTEREST}

The authors declare that there is no conflict of interest.

\section{REFERENCES}

1. Snyder JD, Merson MH. The magnitude of the global problem of acute diarrheal disease: a review of active surveillance data. Bull World Health Organ 1982; 60:605-613.

2. Gasparini EA, Portella R. Particularidade das Infecções por Protozoários In: Manual de Parasitoses Intestinais. $1^{\text {st }}$ ed. Rio de Janeiro: Rubio; 2004. p. 117.

3. Cimerman S. Prevalência de Parasitoses Intestinais em Pacientes Portadores de Síndrome da Imunodeficiência Adquirida (AIDS). [Thesis]. [São Paulo]: Universidade Federal de São Paulo; 1998. 97 p.

4. Rachid M, Schechter M. Afecções do Trato Digestivo. In: Manual HIV/AIDS. $8^{\text {th }}$ ed. Rio de Janeiro: Revinter; 2005. p. 82.

5. Johnson EH, Windsor JJ, Clark CG. Emerging from obscurity: biological, clinical, and diagnostic aspects of Dientamoeba fragilis. Clin Microbiol Rev 2004; 17:553-570
6. Gryschek RCB, Tuon FF. Outras amebas intestinais e protozoários comensais. In: Amato Neto V, Amato VS, Tuon FF, Gryschek RCB, editors. Parasitologia Uma Abordagem Clínica. $1^{\text {st }}$ ed. São Paulo: Elsevier; 2008. p. 30-31.

7. Hoffmann WA, Pons JA, Janer JL. Sedimentation concentration method in schistosomiasis, Puerto Rico. J Public Health 1934; 9:283-298.

8. Ritchie LS. An ether sedimentation technique for routine stool examination Bull United State Army Medical Department 1948; 8:326.

9. Sodré FC, Franco RM. Novos aspesctos sobre um tema bem conhecido: Cryptosporidium. Rev Bras Analises Clinicas 2001; 33:97-106.

10. Horen WP. Modification of Schaudinn fixative. J Clin Microbiol 1981; 13: 204-205.

11. Garcia LS. Diagnostic Medical Parasitology. $5^{\text {th }}$ ed. Washington (DC): ASM Press; 2007.

12. Méndez OC, Szmulewicz G, Menghi C, Torres S, González G, Gatta C Comparison of intestinal parasite infestation indexes among HIV positive and negative populations [Article in Spanish]. Medicina (B Aires) 1994; 54:307-310.

13. Lagacé-Wiens RP, VanCaeseele GP, Koschik C. Dientamoeba fragilis: an emerging role in intestinal disease. Can Med Assoc J 2006; 175:777.

14. Girginkardesler N, Coskun S, Cüneyt Balcioðlu I, Ertan P, Ok UZ. Dientamoeba fragilis, a neglected cause of diarrhea, successfully treated with secnidazole. Clin Microbiol Infect 2003; 9:110-113.

15. Stark D, Barratt J, Roberts T, Marriott D, Harkness J, Ellis J. A review of the clinical presentation of dientamoebiasis. Am J Trop Med Hyg 2010; 82:614-619.

16. Lainson R, Silva BA. Intestinal parasites of some diarrhoeic HIV-seropositive individuals in North Brazil, with particular reference to Isospora belli Wenyon, 1923 and Dientamoeba fragilis Jepps \& Dobell, 1918. Mem Inst Oswaldo Cruz 1999; 94:611-613. 